\title{
Annual prizes and awards 1995 (Scottish Division)
}

\section{McHarg Essay Prize (value 8400)}

The McHarg Prize is awarded for the best essay written on any subject related to psychiatry by a psychiatric trainee working in Scotland. There is no specific length of essay.

\section{Merck Lipha Research/travel Award (value \&1500)}

The Merck Lipha Award is open to psychiatric trainees and newly appointed consultant psychiatrists (within two years of first consultant appointment) working in Scotland. Applicants are invited to submit a research project or a proposed study tour with supporting information including the purpose of the proposed study/trip, its rationale, candidate's relevant experience, $\mathrm{CV}$ and the name of a referee.

\section{Dista Audit Award (value 8500)}

The Dista Award is open to psychiatric trainees working in Scotland. Applicants are invited to submit a report of an audit in a form suitable for publication. Entries will be judged on the quality of the written report. While applicants are expected to have played some part in the audit, it does not have to be a major part, so even junior trainees should be eligible.

\section{Lundbeck Medical Student Prizes (value: four prizes of $\$ 100$ )}

Applicants are invited to write a short piece relating their experience of psychiatry during their attachment to a psychiatric team. It may be critical, impressionistic, witty, amusing. Submissions will probably be in the region of 500 to 1000 words but any length will be accepted. One prize will be awarded to a student from each of the four Scottish Medical Schools.

The closing date for all the prizes/awards is 31 October 1995. The judges will be the Chairman and the Secretary of the Scottish Division and one Professor of Psychiatry. Prizes will be presented at the Winter Meeting of the Scottish Division on 24 November 1995 in Edinburgh. Prizewinners (with the exception of the Lundbeck prizes) will be invited to present their work at a future clinical meeting of the Scottish Division. Please send three copies to the Honorary Secretary of the Dtvision at 9 Queen Street, Edinburgh EH2 1JQ. Entries for the Medical Student prize may be typed or hand-written (if legible).

\section{Corrigendum}

Contrary to details given in a previous issue of the Psychiatric Bulletin, the correct address for the Irish Office of the Royal College of Psychiatrists is as follows: 37 Carysfort Downs, Blackrock, Co. Dublin (fax: 003531 278 1995). 